\title{
Neurobiological effects of transcranial direct current stimulation: a review
}

\section{Liciane Fernandes Medeiros ${ }^{1,2,3 \dagger}$, Izabel Cristina Custodio de Souza ${ }^{3,4 \dagger}$, Liliane Pinto Vidor ${ }^{2,3,4}$, Andressa de Souza ${ }^{2,3,4}$, Alícia Deitos ${ }^{2,3,4}$, Magdalena Sarah Volz ${ }^{5}$, Felipe Fregni ${ }^{6}$, Wolnei Caumo ${ }^{2,3,4}{ }^{*}$ and Iraci L. S. Torres ${ }^{1,2,3,4}$}

${ }_{1}^{1}$ Post-Graduate Program in Biological Sciences, Department of Physiology, Universidade Federal do Rio Grande do Sul, Porto Alegre, Brazil

${ }_{2}^{2}$ Pharmacology Department, Institute of Basic Health Science, Universidade Federal do Rio Grande do Sul, Porto Alegre, Brazil

${ }^{3}$ Laboratory of Pain and Neuromodulation, Hospital de Clínicas de Porto Alegre, Porto Alegre, Brazil

${ }^{4}$ Post-Graduate Program in Medical Sciences, School of Medicine, Universidade Federal do Rio Grande do Sul, Porto Alegre, Brazil

${ }^{5}$ Charité - Universitätsmedizin Berlin, Berlin, Germany

${ }^{6}$ Laboratory of Neuromodulation, Department of Physical Medicine and Rehabilitation, Harvard Medical School, Spaulding Rehabilitation Hospital and Massachusetts General Hospital, Boston, MA, USA

\section{Edited by:}

Paulo Sérgio Boggio, Mackenzie

Presbyterian University, Brazil

Reviewed by:

John Hart, University of Texas at

Dallas, USA

Kate Hoy, Monash University,

Australia

*Correspondence:

Wolnei Caumo, Laboratory of Pain and Neuromodulation, Hospital de

Clínicas de Porto Alegre, Rua Ramiro Barcelos, 2350-CEP 90035-003

Bairro Rio Branco, Porto Alegre, Rio

Grande do Sul, Brazil.

e-mail: caumo@cpovo.net

${ }^{+}$Liciane Fernandes Medeiros and Izabel Cristina Custodio de Souza have contributed equally to this work.
Transcranial Direct Current Stimulation (tDCS) is a non-invasive brain stimulation technique that is affordable and easy to operate compared to other neuromodulation techniques. Anodal stimulation increases cortical excitability, while the cathodal stimulation decreases it. Although tDCS is a promising treatment approach for chronic pain as well as for neuropsychiatric diseases and other neurological disorders, several complex neurobiological mechanisms that are not well understood are involved in its effect. The purpose of this systematic review is to summarize the current knowledge regarding the neurobiological mechanisms involved in the effects of tDCS. The initial search resulted in 171 articles. After applying inclusion and exclusion criteria, we screened 32 full-text articles to extract findings about the neurobiology of tDCS effects including investigation of cortical excitability parameters. Overall, these findings show that tDCS involves a cascade of events at the cellular and molecular levels. Moreover, tDCS is associated with glutamatergic, GABAergic, dopaminergic, serotonergic, and cholinergic activity modulation. Though these studies provide important advancements toward the understanding of mechanisms underlying tDCS effects, further studies are needed to integrate these mechanisms as to optimize clinical development of tDCS.

Keywords: tDCS, neurobiology, neuromodulation, functional effects, long-term depression, long-term potentiation

\section{INTRODUCTION}

Transcranial Direct Current Stimulation (tDCS) has been utilized for the modulation of cortical excitability (Nitsche and Paulus, 2000; Fregni et al., 2005; Dieckhöfer et al., 2006; Nitsche et al., 2007; Wagner et al., 2007b) in various diseases, such as depression, chronic pain, stroke, and Parkinson's disease (Hansen et al., 2010; Lindenberg et al., 2010; Antal and Paulus, 2011; Borckardt et al., 2011, 2012; Riberto et al., 2011; DaSilva et al., 2012; Knotkova et al., 2012; Kumru et al., 2012). tDCS consists of applying direct current (DC) over the scalp using electrodes that are enclosed in perforated sponge pockets soaked with a saline solution or a rubber electrode with conductive gel (Vanneste et al., 2010; DaSilva et al., 2011). It effects depend on the following factors: the size, polarity and position of the electrodes, the applied current intensity, the density and duration of stimulation, and the properties of the tissue in the stimulated area.

This technique can induce long-lasting and polarity-specific changes in the excitability of the motor cortex in humans (Nitsche and Paulus, 2001; Lang et al., 2004). Depending on the current flow, it can increase or decrease neuronal excitability. The mechanisms are electrode-dependent and involve either (1) membrane depolarization (increased spontaneous firing and excitability of the cortical neurons for anodal stimulation) or (2) membrane hyperpolarization (decreased neuronal firing and excitability for cathodal stimulation; Nitsche and Paulus, 2000, 2001; Nitsche et al., 2003a). In the most commonly used procedure, one electrode is placed over a specific site while the other reference electrode is placed over another location to complete the circuit of current flow. The electrode positioning is critical for determining the direction and spatial distribution of the current flow and, ultimately, the effectiveness of the treatment (Utz et al., 2010).

The exact pathways involved in the effects of tDCS are not fully understood (Wagner et al., 2007a; Utz et al., 2010; Stagg and Nitsche, 2011). Thus, more studies to support its clinical application are needed. It is known that weak fields are the basis of the biological effects of tDCS. It is thought that the application of an electric field with sufficient strength and duration can cause a rapid increase in the electrical conductance of biological membranes. This is associated with an increased permeability for ions and small and large molecules. However, the knowledge about the effects on neurotransmission, neurochemical markers, neural pathways, neural tracts, or neural interfaces is incomplete. 
Few $\mathrm{tDCS}$ studies have been published that assess its underlying neurobiological mechanism. Thus, there is need for further studies to broaden our understanding of the possible neurochemical and neurobiological mechanisms involved. In addition, a better understanding of its possible mechanisms is essential to advance the research and to support its application in a clinical setting. Currently, there are only 123 clinical trials published in English using tDCS. We found 32 studies that assessed the some neurobiological mechanisms.

Neurophysiologists have shown great interest in investigating the effects of low-intensity electrical stimulation, in which the currents used are typically equal to or less than $2 \mathrm{~mA}$, applied to humans (Zaghi et al., 2009). However, studies in human are sometimes insufficient to understand the underlying mechanisms. To address this, we use the translational approach of animal research. The purpose of this review is to summarize the current knowledge and to improve the understanding of the neurobiological mechanisms that may be involved in the effects of tDCS. Moreover, we aim to reveal novel insights into the mechanism of action of the observed clinical responses.

\section{METHODS}

This systematic review is based on a literature search using PubMed, Web of Science, OVID MEDLINE, and the Cochrane Library. The keyword "tDCS" was used in combination with other keywords such as "pain," "chronic pain," "depression," "Parkinson," "stroke," "cell mechanisms," "neurobiological mechanisms," "functional effects," "intracellular effects," "receptor," "long-term depression (LTD)," and "long-term potentiation (LTP)." The term "AND/OR" was used in each combination. The reference sections of the studies that met our inclusion criteria were also manually screened for relevant publications.

\section{INCLUSION CRITERIA}

Studies had to meet the following criteria: (1) published in English between 2002 and 2012, (2) report original research, (3) tDCS, (4) the main factors of interest were neurotransmitters, peptides, neurochemical markers, neural pathways, neural tracts, or neural interfaces, and (5) had outcome measures regarding changes in symptoms or electrophysiological or biochemical parameters. Full-text records of each retrieved article were reviewed to determine which studies would be included. We collected information regarding neurobiological mechanisms from human, animal, and cell-culture studies. Moreover, we extracted information on cortical parameters. We systematically screened all articles for the following information: experimental design, sample size, stimulation details (stimulation paradigm and parameters), and main results regarding neurobiological mechanisms. As this review is mainly focused on the neurobiology of tDCS effects, we did not conduct statistical analyses, but instead summarize the results in a narrative format. The exclusion criterion was a lack of original data, such as review articles.

\section{RESULTS}

The final search identified 171 studies. After applying the inclusion and exclusion criteria, we included 32 studies for full-text analysis. We screened the articles according to neurobiological mechanisms, and summarized the results separately for in vivo (humans and animals) and in vitro studies. Tables 1-4 show the main findings.

\section{NEUROBIOLOGICAL MECHANISMS}

One of the most common ways that we can improve our understanding of neurobiological mechanisms is through pharmacological intervention. Numerous studies have attempted to understand the mechanism of action related to the tDCS neuromodulation technique (Liebetanz et al., 2002; Nitsche et al., 2006; Monte-Silva et al., 2009). It is important to note that these investigations include healthy volunteers as well as patients. In addition, in vitro studies and experimental research in animal models can help elucidate the possible mechanisms involved in tDCS.

\section{In vivo - humans}

A total of 20 articles reported tDCS experiments in humans. The results are presented in Table 1 . Most of the articles used pharmacological interventions to characterize the after-effects of tDCS, some of them analyzing the short and long-lasting effects after tDCS. The use of drugs that interact in diverse systems, such as GABAergic, serotoninergic, and cholinergic, can contribute to clarify the some of the neurobiological mechanisms of action related to after-effects of tDCS. The results from these studies demonstrate that a variety of systems can be involved in the mechanisms of action of tDCS. All these articles investigated healthy subjects, except for one case report (Antal and Paulus, 2011).

\section{In vitro}

A total of six articles reported basic DC experiment. The results are given in Table 2. Studies in vitro can bring us the membrane and intracellular mechanisms involved in the effects of DC stimulation. The studies described that the intracellular calcium can be related to one pathway mechanism of tDCS. The BDNF-secretion may be other pathway that can explain the after-effects of DC stimulation.

\section{In vivo - animals}

A total of three articles reported DC stimulation experiments in animals. The results are summarized in Table 3 . These results demonstrate that DC stimulation can promote neuroprotective or neuroplasticity effects in rat animal models. In addition, it was demonstrated modulation in the learning process after stimulation using rabbits.

\section{CORTICAL EXCITABILITY}

We included four articles that associated cortical excitability parameters with neurobiological mechanisms. The parameters of cortical excitability can contribute to a better understanding of the effects of neuromodulatory techniques, such as tDCS. Transcranial magnetic stimulation (TMS) is a tool that can be used for evaluating the parameters of cortical excitability in response to neurostimulatory interventions. The results demonstrated the polarity-specific response of tDCS, anodal stimulation increases MEPs and cathodal decreases it. Most of studies were performed in healthy subjects. The results are given in Table 4. 


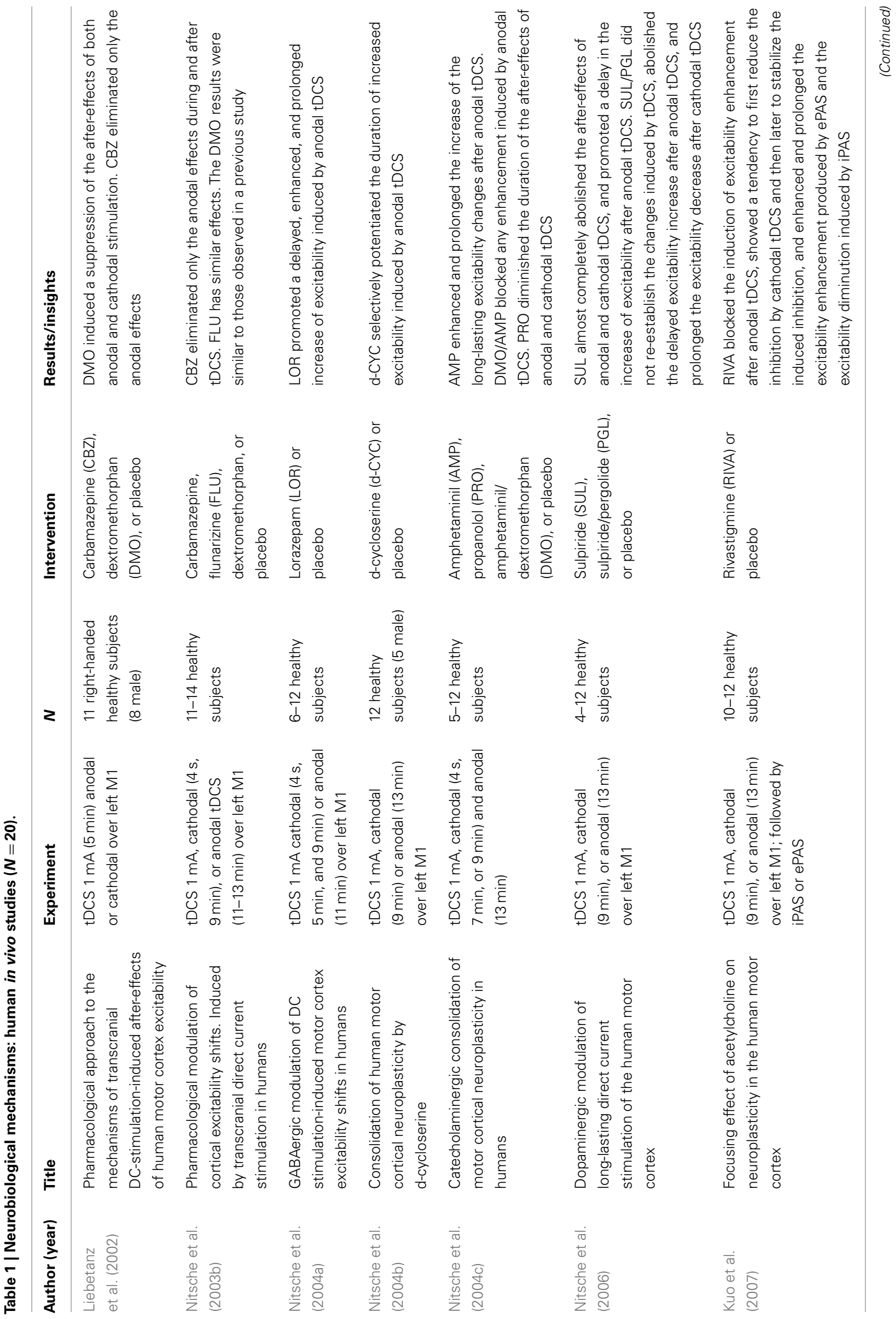




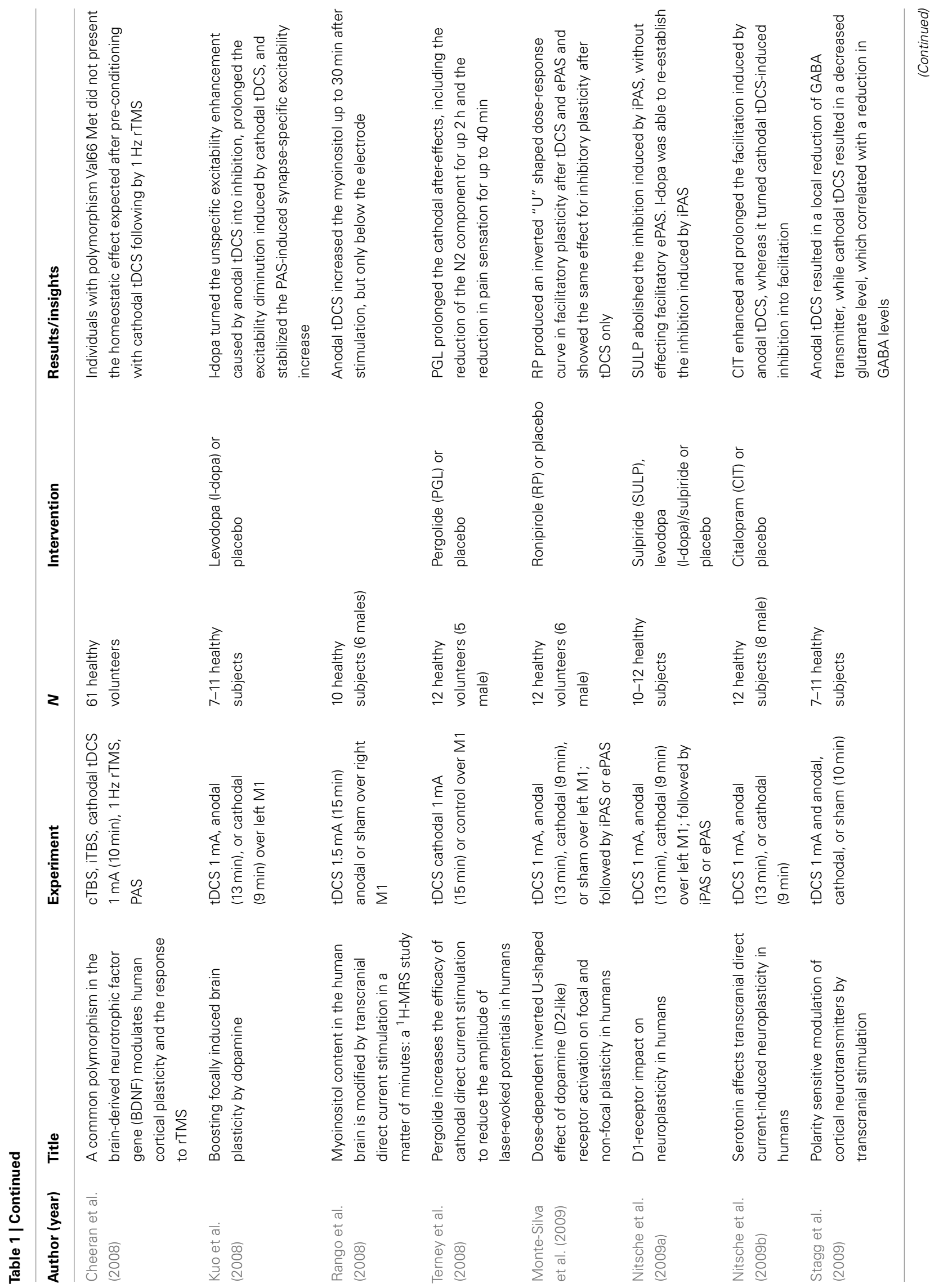




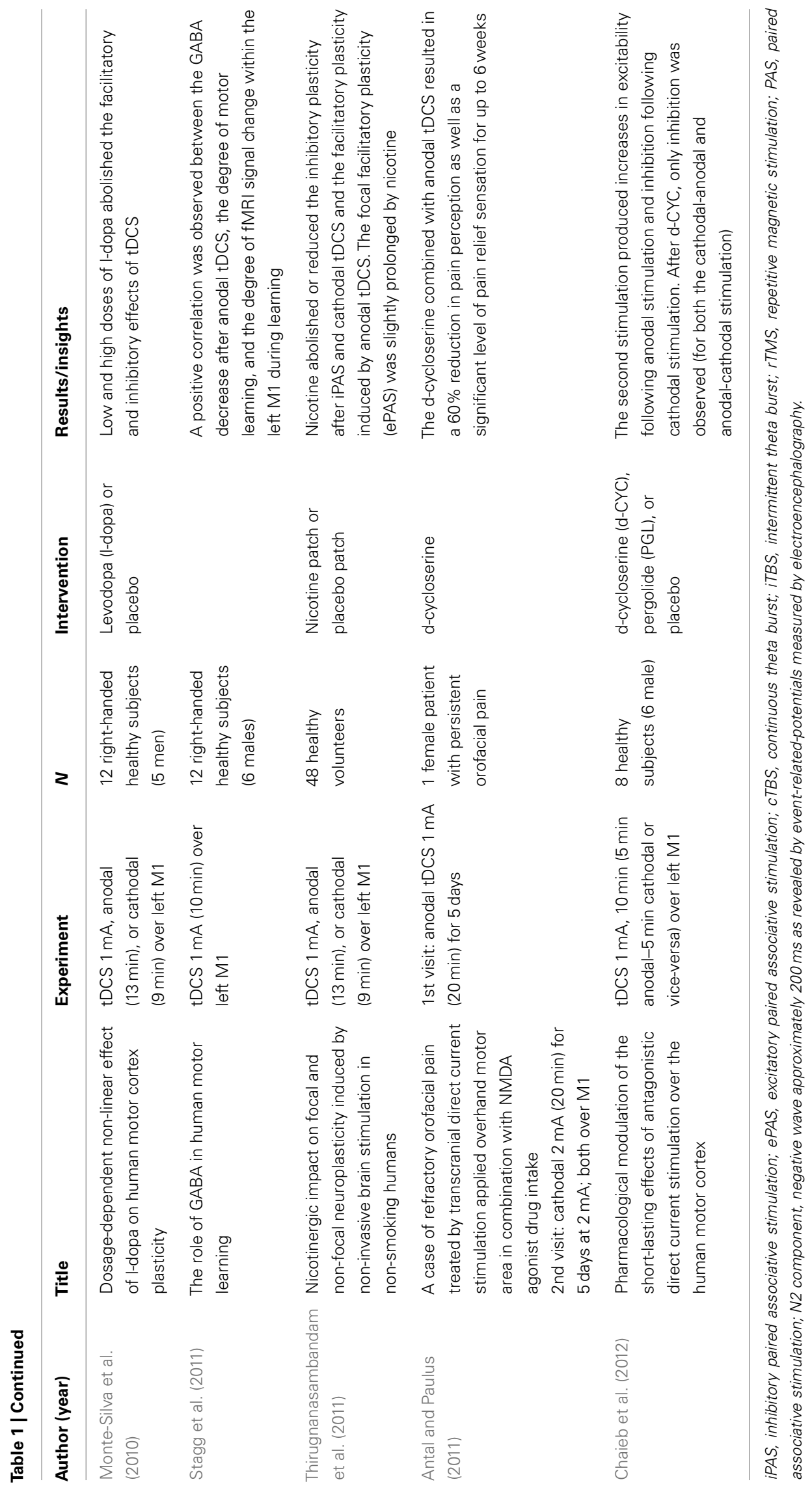


Table 2 | Neurobiological mechanisms: in vitro studies $(N=6)$.

\begin{tabular}{|c|c|c|c|c|c|}
\hline Author (year) & Title & Experiment & $N$ & Model & Results/insights \\
\hline $\begin{array}{l}\text { Khatib et al. } \\
\text { (2004) }\end{array}$ & $\begin{array}{l}\text { Physiologic electrical } \\
\text { stimulation provokes } \\
\text { intracellular calcium } \\
\text { increase mediated by } \\
\text { phospholipase C } \\
\text { activation in human } \\
\text { osteoblasts }\end{array}$ & $\begin{array}{l}\text { Electrical stimulation, } \\
2 \mathrm{~V} / \mathrm{cm}\end{array}$ & $\begin{array}{l}\text { Cells at } 60-70 \% \\
\text { confluence }\end{array}$ & $\begin{array}{l}\text { Osteoblasts cell } \\
\text { culture }\end{array}$ & $\begin{array}{l}\text { Electrical stimulation promoted an } \\
\text { increase in }\left[\mathrm{Ca}^{2+}\right]_{i} \text { that showed a } \\
\text { partial inhibition after blocking cation } \\
\text { channels or chelating }\left[\mathrm{Ca}^{2+}\right]_{i} \text {. A } \\
\text { phospholipase } \mathrm{C} \text { inhibitor } \\
\text { completely abolished the }\left[\mathrm{Ca}^{2+}\right]_{i} \\
\text { increase }\end{array}$ \\
\hline $\begin{array}{l}\text { Radman et al. } \\
\text { (2009) }\end{array}$ & $\begin{array}{l}\text { Role of cortical cell type } \\
\text { and morphology in } \\
\text { subthreshold and } \\
\text { suprathreshold uniform } \\
\text { electric field stimulation } \\
\text { in vitro }\end{array}$ & $\begin{array}{l}\text { DC stimulation, anodal } \\
\sim 5 \mathrm{mV} / \mathrm{mm} \text { up to } \\
\sim \pm 30 \mathrm{mV} / \mathrm{mm}\end{array}$ & $\begin{array}{l}\text { Coronal slices } \\
(300 \mu \mathrm{m}) \text { of } \\
\text { primary motor } \\
\text { cortex (M1) }-51 \\
\text { neurons } \\
\text { (Pyramidal cells) }\end{array}$ & Tissue model & $\begin{array}{l}\text { The cells responded to DC in a } \\
\text { subthreshold and suprathreshold } \\
\text { uniform electric field. The } \\
\text { importance of the morphology and } \\
\text { type of cell in mediating the } \\
\text { response to the stimulus was } \\
\text { discussed }\end{array}$ \\
\hline $\begin{array}{l}\text { Fritsch et al. } \\
\text { (2010) }\end{array}$ & $\begin{array}{l}\text { Direct stimulation } \\
\text { promotes } \\
\text { BDNF-dependent } \\
\text { synaptic plasticity: } \\
\text { potential implication for } \\
\text { motor learning }\end{array}$ & DC stimulation $10 \mu \mathrm{A}$ & Not described & $\begin{array}{l}\text { Coronal mouse } \\
\text { slices }\end{array}$ & $\begin{array}{l}\text { They proposed that DCS could } \\
\text { induce synaptic plasticity in vitro in } \\
\text { brain regions that do not respond to } \\
\text { conventional protocols. This was } \\
\text { dependent on enhanced } \\
\text { BDNF-secretion and TrkB-activation }\end{array}$ \\
\hline $\begin{array}{l}\text { Dubé et al. } \\
\text { (2012) }\end{array}$ & $\begin{array}{l}\text { Human keratinocytes } \\
\text { respond to direct } \\
\text { stimulation by } \\
\text { increasing intracellular } \\
\text { calcium: preferential } \\
\text { response of poorly } \\
\text { differentiated cells }\end{array}$ & $\begin{array}{l}\text { Electrical field of } \\
200 \mathrm{mV} / \mathrm{mm}\end{array}$ & $\begin{array}{l}\text { The cells were } \\
\text { plated into six } \\
\text { wells culture } \\
\text { dishes) cells } / \mathrm{cm}^{2} \\
\text { and cultured until } \\
80 \% \text { confluence } \\
\text { was reached }\end{array}$ & $\begin{array}{l}\text { Keratinocytes cell } \\
\text { culture }\end{array}$ & $\begin{array}{l}\text { Stimulation induced an increase in } \\
\text { intracellular }\left[\mathrm{Ca}^{2+}\right] \text {. The extracellular } \\
\text { calcium was responsible for this } \\
\text { increase, and it was mediated in } \\
\text { part by L-type voltage-gated calcium } \\
\text { channels. The increase was only } \\
\text { detected in involucrin-negative } \\
\text { keratinocytes }\end{array}$ \\
\hline $\begin{array}{l}\text { Ruohonen and } \\
\text { Karhu (2012) }\end{array}$ & $\begin{array}{l}\text { tDCS possibly } \\
\text { stimulates glial cells }\end{array}$ & $\begin{array}{l}\text { DC stimulation in } \\
\text { E-field - 2-mA current } \\
\text { for tDCS - } 20 \mathrm{mV} \\
(2 \mathrm{~mA} / 50 \mathrm{~mA})=0.8 \mathrm{mV}\end{array}$ & $\begin{array}{l}\text { Theoretical } \\
\text { analysis }\end{array}$ & Glial cells & $\begin{array}{l}\text { They considered the possibility of } \\
\text { glial mechanisms could be } \\
\text { modulated by tDCS }\end{array}$ \\
\hline $\begin{array}{l}\text { Ranieri et al. } \\
\text { (2012) }\end{array}$ & $\begin{array}{l}\text { Modulation of LTP at rat } \\
\text { hippocampal CA3-CA1 } \\
\text { synapses by direct } \\
\text { current stimulation }\end{array}$ & $\begin{array}{l}\text { DCS anodal or cathodal, } \\
50 \text { stimuli at } 100 \mathrm{~Hz} \\
\text { ( } 500 \mathrm{~ms} \text { each) repeated } \\
\text { every } 20 \mathrm{~s}\end{array}$ & Not described & $\begin{array}{l}\text { Hippocampal slices } \\
\text { from male Wistar } \\
\text { rats }\end{array}$ & $\begin{array}{l}\text { They suggested that tDCS can } \\
\text { modulate LTP in intact human brain }\end{array}$ \\
\hline
\end{tabular}

$D C$, direct current stimulation; $\left[\mathrm{Ca}^{2+}\right]_{i}$, calcium intracellular; BDNF, brain-derived neurotrophic factor; TrkB, tyrosine kinase B; LTP, long-term potentiation.

\section{DISCUSSION}

Overall, we reviewed 32 articles in full-text extracting the main findings of tDCS on neurobiological mechanisms. TDCS effects appear to be multifactorial and capable to induce changes in different systems. Thus, the effects underlying tDCS cannot be simplified to only one mechanism. tDCS induces physiological changes that result in local and distant plastic changes. Some of the tDCS effects seem to be associated with homeostatic effects in a facilitatory and/or inhibitory way.

The studies reviewed in this article demonstrate that the plastic changes induced by tDCS involve regulation of a broad variety of neurotransmitters including dopamine, acetylcholine, and serotonin (Kuo et al., 2007; Monte-Silva et al., 2009; Nitsche et al., 2009b), and also affect a variety of different neuronal membrane channels, such as sodium and calcium. Furthermore the induction of tDCS after-effects is associated with synaptic modulation. The after-effects of anodal and cathodal tDCS are influenced by the potentiation of synaptic glutamatergic receptors (Nitsche et al., 2003b). Furthermore, anodal tDCS is also influenced by GABAergic neurotransmission via interneurons (Nitsche et al., 2004a).

We showed several consistent pharmacological approaches to understand the mechanisms of tDCS (Table 1). The DMO (a NMDA-receptor antagonist) induces suppression of the 
Table 3 | Neurobiological mechanisms: in vivo animals $(N=3)$.

\begin{tabular}{|c|c|c|c|c|}
\hline Author (year) & Title & Experiment & $N$ & Results/insights \\
\hline $\begin{array}{l}\text { Kim et al. } \\
\text { (2010) }\end{array}$ & $\begin{array}{l}\text { Functional and histological changes } \\
\text { after repeated transcranial direct } \\
\text { current stimulation in a stroke model }\end{array}$ & $\begin{array}{l}\text { Anodal or cathodal tDCS, } \\
0.1 \mathrm{~mA} \text { for } 30 \text { min for } 2 \text { weeks }\end{array}$ & $\begin{array}{l}41 \text { Sprague- } \\
\text { Dawley } \\
\text { rats }\end{array}$ & $\begin{array}{l}\text { Anodal stimulation showed a neuroprotective } \\
\text { effect (functional improvement and } \\
\text { well-preserved white matter axons) }\end{array}$ \\
\hline $\begin{array}{l}\text { Márquez-Ruiz } \\
\text { et al. (2012) }\end{array}$ & $\begin{array}{l}\text { Transcranial direct current stimulation } \\
\text { modulates synaptic mechanisms } \\
\text { involved in associative learning in } \\
\text { behaving rabbits }\end{array}$ & $\begin{array}{l}\text { Anodal or cathodal tDCS from } \\
0.5 \text { to } 2 \mathrm{~mA} \text { (immediate } \\
\text { effects) and } 1 \mathrm{~mA} \text { for } 20 \mathrm{~min} \\
\text { (after-effects) over } \\
\text { somatosensory (S1) cortex }\end{array}$ & 13 rabbits & $\begin{array}{l}\text { Associative learning is modulated by tDCS. } \\
\text { Changes were observed in the amplitude and } \\
\text { area of the S1 components following anodal or } \\
\text { cathodal stimulation. tDCS modulates } \\
\text { paired-pulse responses. LTD evoked in the } \\
\text { somatosensory cortex after cathodal tDCS is } \\
\text { prevented by blocking adenosine A1 receptors }\end{array}$ \\
\hline $\begin{array}{l}\text { Yoon et al. } \\
\text { (2012) }\end{array}$ & $\begin{array}{l}\text { Functional improvement and } \\
\text { neuroplastic effects of anodal } \\
\text { transcranial direct current stimulation } \\
\text { (tDCS) delivered } 1 \text { day vs. } 1 \text { week after } \\
\text { cerebral ischemia in rats }\end{array}$ & $\begin{array}{l}\text { Anodal or sham tDCS, } 0.2 \mathrm{~mA} \\
\text { for } 20 \text { min for } 5 \text { days }\end{array}$ & $\begin{array}{l}30 \text { male } \\
\text { Sprague- } \\
\text { Dawley } \\
\text { rats }\end{array}$ & $\begin{array}{l}\text { Anodal tDCS modulated neural plasticity } \\
\text { around the ischemic penumbra and even in } \\
\text { the contralesional area without aggravating the } \\
\text { infarction volume or causing metabolic } \\
\text { alterations }\end{array}$ \\
\hline
\end{tabular}

LTD, long-term depression.

Table 4 | Cortical parameters $(N=4)$.

\begin{tabular}{|c|c|c|c|c|}
\hline Author (year) & Title & Experiment & $N$ & Results/insights \\
\hline $\begin{array}{l}\text { Lang et al. } \\
(2004)\end{array}$ & $\begin{array}{l}\text { Effects of tDCS stimulation } \\
\text { over the human motor cortex } \\
\text { on corticospinal and } \\
\text { transcallosal excitability }\end{array}$ & $\begin{array}{l}\text { tDCS } 1 \mathrm{~mA} \text { anodal or } \\
\text { cathodal (10 min) } \\
\text { over left M1 }\end{array}$ & $\begin{array}{l}8 \text { right-handed healthy } \\
\text { subjects ( } 5 \text { male) }\end{array}$ & $\begin{array}{l}\text { Increased or decreased MEPs according to the } \\
\text { specific polarity in the left hemisphere. The duration } \\
\text { of TC evoked from the right M1 was shortened or } \\
\text { prolonged according to the specific polarity }\end{array}$ \\
\hline $\begin{array}{l}\text { Hasan et al. } \\
\text { (2011) }\end{array}$ & $\begin{array}{l}\text { Dysfunctional long-term } \\
\text { potentiation-like plasticity in } \\
\text { schizophrenia revealed by } \\
\text { tDCS }\end{array}$ & $\begin{array}{l}\text { tDCS } 1 \mathrm{~mA} \text { (3 min) } \\
\text { anodal over left M1 }\end{array}$ & $\begin{array}{l}44 \text { individuals ( } 22 \\
\text { paranoid schizophrenia } \\
\text { were compared with } 22 \\
\text { matched healthy } \\
\text { subjects) }\end{array}$ & $\begin{array}{l}\text { Anodal tDCS resulted in a reduction in LTP-like } \\
\text { plasticity in multi-episode schizophrenia patients } \\
\text { compared to recent-onset schizophrenia patients } \\
\text { and healthy controls. All schizophrenia patients } \\
\text { demonstrated reduced cortical inhibition }\end{array}$ \\
\hline $\begin{array}{l}\text { Polanía et al. } \\
\text { (2011) }\end{array}$ & $\begin{array}{l}\text { Introducing graph theory to } \\
\text { track for neuroplastic } \\
\text { alterations in the resting } \\
\text { human brain: a tDCS study }\end{array}$ & $\begin{array}{l}\text { tDCS } 1 \mathrm{~mA}(10 \mathrm{~min}) \\
\text { anodal or sham over } \\
\text { left M1 }\end{array}$ & $\begin{array}{l}13 \text { healthy volunteers ( } 6 \\
\text { male) }\end{array}$ & $\begin{array}{l}\text { Anodal tDCS increased the nodal minimum path } \\
\text { lengths in the left somatomotor (SM1) cortex, i.e., } \\
\text { the number of direct functional connections from } \\
\text { the left SM1 to the topologically distant gray matter } \\
\text { voxels was significantly decreased. The functional } \\
\text { coupling between the premotor and superior parietal } \\
\text { areas with the left SM1 was significantly increased. } \\
\text { The nodal connectivity degree in the left posterior } \\
\text { cingulated cortex area and in the right DLPFC was } \\
\text { significantly increased }\end{array}$ \\
\hline $\begin{array}{l}\text { Scelzo et al. } \\
(2011)\end{array}$ & $\begin{array}{l}\text { Increased short latency } \\
\text { afferent inhibition after anodal } \\
\text { tDCS }\end{array}$ & $\begin{array}{l}\text { tDCS } 1 \mathrm{~mA} \text { (13 min) } \\
\text { anodal over primary } \\
\text { motor cortex }\end{array}$ & 12 subjects (4 male) & $\begin{array}{l}\text { Anodal tDCS promoted increased short latency } \\
\text { afferent inhibition (SAI), which can be related to } \\
\text { central cholinergic interneuronal circuits }\end{array}$ \\
\hline
\end{tabular}

M1, primary motor cortex; MEPSs, motor evoked potentials; TC, transcallosal inhibition; LTP, long-term potentiation; DLPFC, dorsolateral prefrontal cortex.

after-effects of both anodal and cathodal stimulation (Liebetanz et al., 2002), while the CBZ (a sodium use-dependent channel blocker) eliminates only the anodal effects (Liebetanz et al., 2002). Similar effect was observed using flunarizine (a calcium channel blocker) in the study of Nitsche et al. (2003c); however with smaller magnitude of effects as compared with carbamazepine. Lorazepam (a GABAergic agonist) and D-cycloserine (D-CYC, a partial NMDA agonist) selectively potentiate the effects of anodal DC with increased excitability (Nitsche et al., 2004a,b). Propranolol (a non-selective $\beta$-adrenergic antagonist) decreases the 
duration of the after-effects of anodal and cathodal stimulation (Nitsche et al., 2006). These data demonstrate the involvement of multiple neurotransmitter functions in the mechanisms of action of tDCS.

Therefore one important concept when understanding the effects of tDCS is to understand that its initial effect on inducing neuronal depolarization or hyperpolarization(Creutzfeldt et al., 1962; Bindman et al., 1964) results also in lasting effects characterized by LTP and LTD like effects (Hattori et al., 1990; Moriwaki, 1991; Islam et al., 1995; Paulus, 2004). These mechanisms are supported by clinical findings, such as enhanced in the learning and antidepressant effects using tDCS over several weeks (Fregni et al., 2006; Boggio et al., 2008; Loo et al., 2010; Brunoni et al., 2011). Overall, these studies provide valuable insights into the mechanisms of action that tDCS exerts on neuronal tissue (for a review, see Nitsche, 2005).

This systematic review also highlights that the anodal effects are associated with modulation of GABAergic interneurons (Nitsche et al., 2004a; Stagg et al., 2009; Stagg and Nitsche, 2011). This effect is evidenced by the effects of tDCS on short-interval intracortical inhibition and intracortical facilitation (Nitsche et al., 2005; Stagg et al., 2009; Stagg and Nitsche, 2011). Given that GABAergic cortical inhibitory interneurons play a role in the early stage of Alzheimer's disease (Koliatsos et al., 2006), modulation of these interneurons by tDCS is a potential disease-modifying mechanism. Also, a previous magnetic resonance spectroscopy (MRS) study found that tDCS reduces GABA cortical concentrations and this effect is correlated with impaired glutamatergic neuronal activity (Stagg et al., 2009). These tDCS effects reduce the imbalance between these excitatory and inhibitory neurotransmitter systems. In contrast, carbamazepine selectively eliminated the anodal effects, suggesting that the anodal tDCS require initially depolarization of neuronal membrane potentials (Liebetanz et al., 2002). Liebetanz et al. (2002) provided pharmacological evidence that the induction of the after-effects of tDCS requires a combination of glutamatergic and membrane mechanisms, similar to the induction of established types of short or long-term neuroplasticity.

An important concept when considering the mechanism of TDCS is its association with other interventions such as behavioral and/or pharmacological interventions. The combined application of cathodal/anodal tDCS and D-CYC (a partial agonist of NMDA receptors) during a motor learning task showed that the excitability diminution induced by cathodal tDCS prior to motor learning, or an excitability enhancement induced by anodal tDCS combined with D-CYC, impairs learning performance. Neurophysiologically, a decrease in MEP amplitude was observed (Chaieb et al., 2012). In studies combining tDCS with pharmacological interventions, authors found that application of nicotine patch reduces both inhibitory plasticity after cathodal tDCS and the facilitatory plasticity induced by anodal tDCS (Thirugnanasambandam et al., 2011), while acetylcholine enhances the synapse-specific cortical excitability after anodal tDCS (Kuo et al., 2007). In addition, the inhibitory effect of rivastigmine (a cholinesterase inhibitor) on neuroplasticity induced by anodal tDCS seems contradictory to the results obtained from animal studies in which LTP was facilitated by cholinergic stimulation (Brocher et al., 1992; Abe et al., 1994; Hasselmo and Barkai, 1995; Patil et al., 1998; Kuo et al., 2007). However, these different results might be due to methodological difference between these studies. It is possible that synapses that are globally modified by tDCS are more susceptible to cholinergic suppression of synaptic transmission during plasticity induction.

Other neuropsychotropic drugs showed similar modulation of tDCS-induced plasticity. In fact, TDCS effects are shortened by propranolol following $13 \mathrm{~min}$ of anodal and $9 \mathrm{~min}$ of cathodal tDCS but does not eliminate those (Nitsche et al., 2004c). Moreover, $\beta$-adrenergic receptor stimulation may have an important role for the effects of amphetaminil (a precursor of amphetamine) to increase the consolidation of externally induced excitability enhancements. Similar to results obtained for the $\beta$-adrenergic receptor in the hippocampus, it has been also shown that dopamine via the D1-receptor facilitates NMDAdependent excitability and facilitates NMDA-dependent LTP through Cyclic-adenosine-monophosphate-dependent (cAMP) mechanisms (Otmakhova and Lisman, 1996, 1998; Bailey et al., 2000). Furthermore, it was shown that a single administration of amphetaminil induces prominent and long-term enhancements of cortical dopamine signaling (Vanderschuren et al., 1999). In this way, prolonged dopaminergic activation could stabilize the tDCS-induced NMDA-receptor-dependent excitability enhancements.

Additionally, tDCS promotes changes in brain-derived neurotrophic factor (BDNF; Fritsch et al., 2010). The BDNF promotes the survival of neurons (Lefaucheur, 2008a,b) and is important for cell proliferation (Tessarollo, 1998). Given the results from the study of Cheeran et al. (2008) demonstrating that a common polymorphism in the BDNF gene modulates human cortical plasticity, BDNF could be a marker (and potentially also a pathway) for assessing the effects of tDCS on the nervous system.

Also, new approaches, such as BOLD fMRI, can provide critical information on the mechanisms of tDCS. Furthermore, assessments during the execution of tasks or tDCS stimulation both alone and in combination with other interventions can provide new insights into tDCS effects. Overall, there are many neuropharmacological and neurophysiological methods that can improve our understanding in the neurobiological mechanisms involved in the therapeutic effects of tDCS intervention.

\section{LIMITATIONS IN THE CURRENT KNOWLEDGE}

Although tDCS is one of the most investigated techniques of non-invasive brain stimulation, there are relatively few studies investigating the neurobiological mechanisms associated with the tDCS (Tables 1-4). This article provides information regarding mechanisms of action of tDCS, however most of the mechanistic literature investigated tDCS-related neuroplasticity in the motor cortex. Although motor cortex related data may be of some relevance for treatment of disorders such as chronic pain and motor rehabilitation after stroke where the targeted area is M1, results from experiments in this area are less relevant for other critical targets such as dorsolateral prefrontal cortex. Further research is needed to determine if mechanisms found in studies investigating $\mathrm{M} 1$ are also relevant to brain target regions. 
Another important issue that has not been adequately addressed is whether the neurophysiological findings can be translated into clinical effects. For instance, whether an increase in excitability induced by anodal tDCS translates into increased motor consolidation. Further larger studies need to address this important question. Finally, it is also important the impact of parameters of stimulation in neuroplasticity - i.e., whether longer periods of stimulation lead to beneficial or harmful effects and also to understand the interaction of tDCS with pharmacological treatment in real clinical practice where patients are taking several medications simultaneously.

\section{CONCLUSION AND PERSPECTIVES}

In this review, we discuss the mechanisms of the action of tDCS as to understand neurobiology and cell-signaling pathways associated with tDCS effects. Although initial tDCS studies, showed that its effects are related to the intensity, polarity, and duration of stimulation and the brain region stimulated, it is still not clear the optimal parameters of stimulation especially given the dynamic changes of brain excitability. Recent studies in animal and cell models have suggested that tDCS induces plasticity, neuronal viability, neuronal morphology, modulates synaptic transmission, and biosynthesis of molecules. TDCS induces a cascade

\section{REFERENCES}

Abe, K., Nakata, A., Mizutani, A., and Saito, H. (1994). Facilitatory but nonessential role of the muscarinic cholinergic system in the generation of long-term potentiation of population spikes in the dentate gyrus in vivo. Neuropharmacology 33, 847-852.

Antal, A., and Paulus, W. (2011). A case of refractory orofacial pain treated by transcranial direct current stimulation applied overhand motor area in combination with NMDA agonist drug intake. Brain Stimul. 4, 117-121.

Bailey, C. H., Giustetto, M., Huang, Y. Y., Hawkins, R. D., and Kandel, E. R. (2000). Is heterosynaptic modulation essential for stabilizing Hebbian plasticity and memory? Nat. Rev. Neurosci. 1, 11-20.

Bindman, L. J., Lippold, O. C., and Redfearn, J. W. (1964). The action of brief polarizing currents on the cerebral cortex of the rat (1) during current flow and (2) in the production of long-lasting after-effects. $J$. Physiol. 172, 369-382.

Boggio, P. S., Rigonatti, S. P., Ribeiro, R. B., Myczkowski, M. L., Nitsche, M. A., Pascual-Leone, A., et al. (2008). A randomized, double-blind clinical trial on the efficacy of cortical direct current stimulation for the treatment of major depression. Int. J. Neuropsychopharmacol. 11, 249-254.

Borckardt, J. J., Bikson, M., Frohman, H., Reeves, S. T., Datta, A., Bansal,
V., et al. (2012). A pilot study of the tolerability and effects of highdefinition transcranial direct current stimulation (HD-tDCS) on pain perception. J. Pain 13, 112-120.

Borckardt, J. J., Romagnuolo, J., Reeves, S. T., Madan, A., Frohman, H., Beam, W., et al. (2011). Feasibility, safety, and effectiveness of transcranial direct current stimulation for decreasing post-ERCP pain: a randomized, sham-controlled, pilot study. Gastrointest. Endosc. 73, 1158-1164.

Brocher, S., Artola, A., and Singer, and noradrenergic receptors facilitate synergistically the induction of long-term potentiation in slices of rat visual cortex. Brain Res. 573, 27-36.

Brunoni, A. R., Ferrucci, R., Bortolomasi, M., Vergari, M., Tadini, L., Boggio, P. S., et al. (2011). Transcranial direct current stimulation (tDCS) in unipolar vs. bipolar depressive disorder. Prog. Neuropsychopharmacol. Biol. Psychiatry 35, 96-101.

Chaieb, L., Antal, A., Terney, D., and Paulus, W. (2012). Pharmacological modulation of the shortlasting effects of antagonistic direct current-stimulation over the human motor cortex. Front. Psychiatry 3:67. doi:10.3389/fpsyt.2012.00067

Cheeran, B., Talelli, P., Mori, F., Koch, G., Suppa, A., Edwards, M., et al. (2008). A common polymorphism in the brain-derived neurotrophic factor W. (1992). Agonists of cholinergic

of events associated with glutamatergic, GABAergic, dopaminergic, serotonergic, and cholinergic activity modulation. In addition, we also show the importance of conducting both experimental and clinical studies to understand tDCS-induced neuroplasticity. Overall, compelling evidence from studies reviewed in this article emphasizes possible approaches to understand the neurobiology of tDCS mechanisms. Additionally, it opens new possibilities for future tDCS research in basic and clinical neuroscience.

\section{ACKNOWLEDGMENTS}

This research was supported by grants from following Brazilian agencies: Committee for the Development of Higher Education Personnel - CAPES - PNPD/CAPES (for Wolnei Caumo and Izabel Cristina Custodio de Souza), CAPES International Cooperation 023/11 (for Liciane Fernandes Medeiros and Izabel Cristina Custodio de Souza); National Council for Scientific and Technological Development - CNPq (Iraci L. S. Torres and Wolnei Caumo); Research Support Foundation of the State of Rio Grande do Sul (FAPERGS) - International Cooperation Program (Magdalena Sarah Volz); Postgraduate Program in Medical Sciences at the School of Medicine of the Federal University of Rio Grande do Sul.

gene (BDNF) modulates human cortical plasticity and the response to rTMS. J. Physiol. 586, 5717-5725.

Creutzfeldt, O. D., Fromm, G. H., and Kapp, H. (1962). Influence of transcortical $\mathrm{d}-\mathrm{c}$ currents on cortical neuronal activity. Exp. Neurol. 5, 436-452.

DaSilva, A. F., Mendonca, M. E., Zaghi, S., Lopes, M., DosSantos, M. F., Spierings, E. L., et al. (2012). tDCS-induced analgesia and electrical fields in painrelated neural networks in chronic migraine headache. Headache 52, 1283-1295.

DaSilva, A. F., Volz, M. S., Bikson, M., and Fregni, F. (2011). Electrode positioning and montage in transcranial direct current stimulation. JOVE 51, $1-11$.

Dieckhöfer, A., Waberski, T. D., Nitsche, M., Paulus, W., Buchner, H., and Gobbelé, R. (2006). Transcranial direct current stimulation applied over the somatosensory cortex: differential effect on low and high frequency SEPs. Clin. Neurophysiol. 117, 2221-2227.

Dubé, J., Rochette-Drouin, O. Lévesque, P., Gauvin, R., Roberge, C. J., Auger, F. A., et al. (2012). Human keratinocytes respond to direct current stimulation by increasing intracellular calcium: preferential response of poorly differentiated cells. J. Cell Physiol. 227, 2660-2667.

Fregni, F., Boggio, P. S., Nitsche, M., Bermpohl, F., Antal, A., Feredoes,
E., et al. (2005). Anodal transcranial direct current stimulation of prefrontal cortex enhances working memory. Exp. Brain Res. 166, 23-30.

Fregni, F., Boggio, P. S., Nitsche, M. A., Marcolin, M. A., Rigonatti, S. P., and Pascual-Leone, A. (2006). Treatment of major depression with transcranial direct current stimulation. Bipolar Disord. 8, 203-204.

Fritsch, B., Reis, J., Martinowich, K., Schambra, H. M., Ji, Y., Cohen, L. G., et al. (2010). Direct current stimulation promotes BDNF-dependent synaptic plasticity: potential implications for motor learning. Neuron 66, 198-204.

Hansen, N., Obermann, M., Poitz, F., Holle, D., Diener, H. C., Antal, A., et al. (2010). Modulation of human trigeminal and extracranial nociceptive processing by transcranial direct current stimulation of the motor cortex. Cephalalgia 31, 661-670.

Hasan, A., Nitsche, M. A., Rein, B., Schneider-Axmann, T., Guse, B., Gruber, O., et al. (2011). Dysfunctional long-term potentiation-like plasticity in schizophrenia revealed by transcranial direct current stimulation. Behav. Brain Res. 224, 15-22.

Hasselmo, M. E., and Barkai, E. (1995). Cholinergic modulation of activity dependent synaptic plasticity in the piriform cortex and associative memory function in a network biophysical simulation. J. Neurosci. 15, 6592-6604. 
Hattori, Y., Moriwaki, A., and Hori, Y. (1990). Biphasic effects of polarizing current on adenosine sensitive generation of cyclic AMP in rat cerebral cortex. Neurosci. Lett. 116, 320-324.

Islam, N., Aftabuddin, M., Moriwaki, A., Hattori, Y., and Hori, Y. (1995). Increase in the calcium level following anodal polarization in the rat brain. Brain Res. 684, 206-208.

Khatib, L., Golan, D. E., and Cho, M. (2004). Physiologic electrical stimulation provokes intracellular calcium increase mediated by phospholipase $\mathrm{C}$ activation in human osteoblasts. FASEB J. 18, 1903-1905.

Kim, S. J., Kim, B. K., Ko, Y. J., Bang, M. S., Kim, M. H., and Han, T. R. (2010). Functional and histologic changes after repeated transcranial direct current stimulation in rat stroke model. J. Korean Med. Sci. 25, 1499-1505.

Knotkova, H., Rosedale, M., Strauss, S. M., Horne, J., Soto, E., Cruciani, R. A., et al. (2012). Using transcranial direct current stimulation to treat depression in HIV-infected persons: the outcomes of a feasibility study. Front. Psychiatry 3:59. doi:10.3389/fpsyt.2012.00059

Koliatsos, V. E., Kecojevic, A., Troncoso, J. C., Gastard, M. C., Bennett, D. A., and Schneider, J. A. (2006). Early involvement of small inhibitory cortical interneurons in Alzheimer's disease. Acta Neuropathol. 112, 147-162.

Kumru, H., Soler, D., Vidal, J., Navarro, X., Tormos, J. M., Pascual-Leone1, A., et al. (2012). The effects of transcranial direct current stimulation with visual illusion in neuropathic pain due to spinal cord injury: an evoked potentials and quantitative thermal testing study. Eur. J. Pain. PMID:22610590. [Epub ahead of print].

Kuo, M. F., Grosch, J., Fregni, F., Paulus, W., and Nitsche, M. A. (2007). Focusing effect of acetylcholine on neuroplasticity in the human motor cortex. J. Neurosci. 27, 14442-14447.

Kuo, M. F., Paulus, W., and Nitsche, M. A. (2008). Boosting focally-induced brain plasticity by dopamine. Cereb. Cortex 18, 648-651.

Lang, N., Nitsche, M. A., Paulus, W., Rothwell, J. C., and Lemon, R. N. (2004). Effects of transcranial direct current stimulation over the human motor cortex on corticospinal and transcallosal excitability. Exp. Brain Res. 156, 439-443.

Lefaucheur, J. P. (2008a). "TMS and pain," in The Oxford Handbook of Transcranial Stimulation, eds Wasserman, E. A., Epstein, C. M.,
Ziemann, U., Walsh, V., Paus, T., and Lisanby, S (New York: Oxford University), 717-736.

Lefaucheur, J. P. (2008b). Use of repetitive transcranial magnetic stimulation in pain relief. Expert Rev. Neurother. 8, 799-808

Liebetanz, D., Nitsche, M. A., Tergau, F., and Paulus, W. (2002). Pharmacological approach to the mechanisms of transcranial DCstimulation-induced after effects of human motor cortex excitability. Brain 125, 2238-2247.

Lindenberg, R., Renga, V., Zhu, L. L., Nair, D., and Schlaug, G. (2010). Bihemispheric brain stimulation facilitates motor recovery in chronic stroke patients. Neurology 75, 2176-2184.

Loo, C. K., Sachdev, P., Martin, D., Pigot, M., Alonzo, A., Malhi, G. S., et al. (2010). A double blind, shamcontrolled trial of transcranial direct current stimulation for the treatment of depression. Int. J. Neuropsychopharmacol. 13, 61-69.

Márquez-Ruiz, J., Leal-Campanario, R., Sánchez-Campusano, R., MolaeeArdekani, B., Wendling, F., Miranda, P. C., et al. (2012). Transcranial direct current stimulation modulates synaptic mechanisms involved in associative learning in behaving rabbits. Proc. Natl. Acad. Sci. U.S.A. 109, 6710-6715.

Monte-Silva, K., Kuo, M. F., Thirugnanasambandam, N., Liebetanz, D., Paulus, W., and Nitsche, M. A. (2009). Dose-dependent inverted Ushaped effect of dopamine (D2like) receptor activation on focal and nonfocal plasticity in humans. J. Neurosci. 29, 6124-6131.

Monte-Silva, K., Liebetanz, D., Grundey, J., Paulus, W., and Nitsche, M. A. (2010). Dosage-dependent nonlinear effect of L-dopa on human motor cortex plasticity. J. Physiol. (Lond.) 588, 3415-3424.

Moriwaki, A. (1991). Polarizing currents increase noradrenaline-elicited accumulation of cyclic AMP in rat cerebral cortex. Brain Res. 544, 248-252.

Nitsche, M. (2005). Pharmacological characterisation and modulation of neuroplasticity in humans. Curr. Neuropharmacol. 3, 217-229.

Nitsche, M. A., Doemkes, S., Karaköse, T., Antal, A., Liebetanz, D., Lang, N., et al. (2007). Shaping the effects of transcranial direct current stimulation of the human motor cortex. J. Neurophysiol. 97, 3109-3117.

Nitsche, M. A., Kuo, M. F., Grosch, J., Bergner, C., Monte-Silva, K., and Paulus, W. (2009a). D1-receptor impact on neuroplasticity in humans. J. Neurosci. 29, 2648-2653.

Nitsche, M. A., Kuo, M. F., Karrasch, R., Wächter, B., Liebetanz, D., and Paulus, W. (2009b). Serotonin affects transcranial direct current-induced neuroplasticity in humans. Biol. Psychiatry 66, 503-508.

Nitsche, M. A., Lampe, C., Antal, A. Liebetanz, D., Lang, N., Tergau, F., et al. (2006). Dopaminergic modulation of long-lasting direct current induced cortical excitability changes in the human motor cortex. Eur. J. Neurosci. 23, 1651-1657.

Nitsche, M. A., Liebetanz, D., Schlitterlau, A., Henschke, U., Fricke, K., Frommann, K., et al. (2004a). GABAergic modulation of DC stimulation-induced motor cortex excitability shifts in humans. Eur. J. Neurosci. 19, 2720-2726.

Nitsche, M. A., Jaussi, W., Liebe$\operatorname{tanz}$, D., Lang, N., Tergau, F., and Paulus, W. (2004b). Consolidation of human cortical neuroplasticity by D-cycloserine. Neuropsychopharmacology 29, 1573-1578.

Nitsche, M. A., Grundey, J., Liebetanz, D., Lang, N., Tergau, F., and Paulus, W. (2004c). Catecholaminergic consolidation of motor cortical neuroplasticity in humans. Cereb. Cortex 14, 1240-1245.

Nitsche, M. A., Nitsche, M. S., Klein, C. C., Tergau, F., Rothwell, J. C., and Paulus, W. (2003a). Level of action of cathodal DC polarisation induced inhibition of the human motor cortex. Clin. Neurophysiol. 114, 600-604.

Nitsche, M. A., Fricke, K., Henschke, U., Schlitterlau, A., Liebetanz, D., Lang, N., et al. (2003b). Pharmacological modulation of cortical excitability shifts induced by transcranial direct current stimulation in humans. J. Physiol. 553, 293-301.

Nitsche, M., Liebetanz, D., Lang, N., Antal, A., Tergau, F., and Paulus, W. (2003c). Safety criteria for transcranial direct current stimulation (tDCS) in humans. Clin. Neurophysiol. 114, 2220-2222.

Nitsche, M. A., and Paulus, W. (2000). Excitability changes induced in the human motor cortex by weak transcranial direct current stimulation. $J$. Physiol. (Lond.) 527, 633-639.

Nitsche, M. A., and Paulus, W. (2001). Sustained excitability elevations induced by transcranial DC motor cortex stimulation in humans. Neurology 57, 1899-1901.

Nitsche, M. A., Seeber, A., Frommann, K., Klein, C. C., Rochford, C., Nitsche, M. S., et al. (2005). Modulating parameters of excitability during and after transcranial direct current stimulation of the human motor cortex. J. Physiol. (Lond.) 568, 291-303.

Otmakhova, N. A., and Lisman, J. E. (1996). D1/D5 dopamine receptor activation increases the magnitude of early long-term potentiation at CA1 hippocampal synapses. J. Neurosci. 16, 7478-7486.

Otmakhova, N. A., and Lisman, J. E. (1998). D1/D5 dopamine receptors inhibit depotentiation at CA1 synapses via cAMP-dependent mechanism. J. Neurosci. 18, 1270-1279.

Patil, M. M., Linster, C., Lubenov, E., and Hasselmo, M. E. (1998). Cholinergic agonist carbachol enables associative long-term potentiation in piriform cortex slices. J. Neurophysiol. 80, 2467-2474.

Paulus, W. (2004). Outlasting excitability shifts induced by direct current stimulation of the human brain. Suppl. Clin. Neurophysiol. 57, 708-714.

Polanía, R., Paulus, W., Antal, A., and Nitsche, M. A. (2011). Introducing graph theory to track for neuroplastic alterations in the resting human brain: a transcranial direct current stimulation study. Neuroimage 54, 2287-2296.

Radman, T., Ramos, R. L., Brumberg, J. C., and Bikson, M. (2009). Role of cortical cell type and morphology in subthreshold and suprathreshold uniform electric field stimulation in vitro. Brain Stimul. 2, 215-228, 228.e1-3.

Rango, M., Cogiamanian, F., Marceglia, S., Barberis, B., Arighi, A., Biondetti, P., et al. (2008). Myoinositol content in the human brain is modified by transcranial direct current stimulation in a matter of minutes: a $1 \mathrm{H}$ MRS study. Magn. Reson. Med. 60, 782-789.

Ranieri, F., Podda, M. V., Riccardi, E., Frisullo, G., Dileone, M., Profice, P., et al. (2012). Modulation of LTP at rat hippocampal CA3CA1 synapses by direct current stimulation. J. Neurophysiol. 107, 1868-1880.

Riberto, M., Alfieri, F. M., Pacheco, K. M. B., Leite, V. D., Kaihami, H. N., Fregni, F., et al. (2011). Efficacy of transcranial direct current stimulation coupled with a multidisciplinary rehabilitation program for the treatment of fibromyalgia. Open Rheumatol. J. 5, 45-50.

Ruohonen, J., and Karhu, J. (2012). tDCS possibly stimulates glial cells. Clin. Neurophysiol. 123, 2006-2009. 
Scelzo, E., Giannicola, G., Rosa, M., Ciocca, M., Ardolino, G., Cogiamanian, F., et al. (2011). Increased short latency afferent inhibition after anodal transcranial direct current stimulation. Neurosci. Lett. 498, 167-170.

Stagg, C. J., Bachtiar, V., and JohansenBerg, H. (2011). The role of GABA in human motor learning. Curr. Biol. 21, 480-484.

Stagg, C. J., Best, J. G., Stephenson, M. C., O'Shea, J., Wylezinska, M., Kincses, Z. T., et al. (2009). Polarity sensitive modulation of cortical neurotransmitters by transcranial stimulation. J. Neurosci. 29, 5202-5206.

Stagg, C. J., and Nitsche, M. A. (2011). Physiological basis of transcranial direct current stimulation. Neuroscientist 17, 37-53.

Terney, D., Bergmann, I., Poreisz, C., Chaieb, L., Boros, K., Nitsche, M. A., et al. (2008). Pergolide increases the efficacy of cathodal direct current stimulation to reduce the amplitude of laser-evoked potentials in humans. J. Pain Symptom Manage. 36, 79-91.

Tessarollo, L. (1998). Pleiotropic functions of neurotrophins in development. Cytokine Growth Factor Rev. 9, 125-137.

Thirugnanasambandam, N., Grundey, J., Adam, K., Drees, A., Skwirba, A. C., Lang, N., et al. (2011). Nicotinergic impact on focal and non-focal neuroplasticity induced by noninvasive brain stimulation in nonsmoking humans. Neuropsychopharmacology 36, 879-886.

Utz, K. S., Dimova, V., Oppenlander, K., and Kerkhoff, G. (2010). Electrified minds: transcranial direct current stimulation (tDCS) and galvanic vestibular stimulation (GVS) as methods of non-invasive brain stimulation in neuropsychology - a review of current data and future implications. Neuropsychologia 48, 2789-2810.

Vanderschuren, L. J., Schoffelmeer, A. N., Mulder, A. H., and De Vries, T. J. (1999). Dopaminergic mechanisms mediating the long-term expression of locomotor sensitization following pre-exposure to morphine or amphetamine. Psychopharmacology (Berl). 143, 244-253.

Vanneste, S., Plazier, M., Ost, J., van der Loo, E., Heyning, P. V., and Ridder, D. (2010). Bilateral dorsolateral prefrontal cortex modulation for tinnitus by transcranial direct current stimulation: a preliminary clinical study. Exp. Brain Res. 202, 779-785.

Wagner, T., Fregni, F., Fecteau, S. Grodzinsky, A., Zahn, M., and Pascual-Leone, A. (2007a). Transcranial direct current stimulation: a computer-based human model study. Neuroimage 35, 1113-1124.

Wagner, T., Valero-Cabre, A., and Pascual-Leone, A. (2007b). Noninvasive human brain stimulation. Annu. Rev. Biomed. Eng. 9, 527.

Yoon, K. J., Oh, B. M., and Kim, D. Y. (2012). Functional improvement and neuroplastic effects of anodal transcranial direct current stimulation (tDCS) delivered 1 day vs. 1 week after cerebral ischemia in rats. Brain Res. 1452, 61-72.

Zaghi, S., Heine, N., and Fregni, F (2009). Brain stimulation for the treatment of pain: a review of costs, clinical effects, and mechanisms of treatment for three different central neuromodulatory approaches. J. Pain Manag. 2, 339-352.
Conflict of Interest Statement: The authors declare that the research was conducted in the absence of any commercial or financial relationships that could be construed as a potential conflict of interest.

Received: 05 July 2012; accepted: 04 December 2012; published online: 28 December 2012.

Citation: Medeiros LF, custodio de Souza IC, Vidor LP, de Souza A, Deitos A, Volz MS, Fregni F, Caumo $W$ and Torres ILS (2012) Neurobiological effects of transcranial direct current stimulation: a review. Front. Psychiatry 3:110. doi: 10.3389/fpsyt.2012.00110

This article was submitted to Frontiers in Neuropsychiatric Imaging and Stimulation, a specialty of Frontiers in Psychiatry. Copyright (c) 2012 Medeiros, de Souza, Vidor, de Souza, Deitos, Volz, Fregni, Caumo and Torres. This is an openaccess article distributed under the terms of the Creative Commons Attribution License, which permits use, distribution and reproduction in other forums, provided the original authors and source are credited and subject to any copyright notices concerning any third-party graphics etc. 